\title{
Volume 125 (2021) Index
}

Published online 13 September 2021

American Journal of Archaeology Volume 125, Number 4

www.ajaonline.org/aja-index/125

DOI: 10.3764 /ajaonline1254.Index

This online-only published content is freely available electronically immediately upon publication and can be distributed under the Creative Commons Attribution-NonCommercial License (CC BY-NC). This license allows anyone to reuse, remix, and build upon the content, as long as it is for legal noncommercial purposes; the new work must credit the author, the $A J A$, and the Archaeological Institute of America. 


\section{Contents of Volume 125 (2021)}

Baughan, E.P. See Özgen et al.

PAGES

Baysal, E.L., and H. Sağlamtimur, Sacrificial Status and Prestige Burials: Negotiating Life, Death, and Identity Through Personal Adornment at Early Bronze Age I Başur Höyük, Turkey . . . . . . . . 3-28

Beckmann, M., Stigmata and the Cupids of Piazza Armerina. . . . . . . . . . . . . . . . . . . . . . . . . .461-69

Calderbank, D., What's in a Vessel's Name? A Relational Text-Object Approach to the Uses of Mesopotamian Pottery . . . . . . . . . . . . . . . . . . . . . . . . . . . 29-64

Carannante, A. See Woźniak et al.

Carlson, D.N., and C. Pulak, George Fletcher Bass (1932-2021) . . . . . . . . . . . . . . . . . .471-74

Carroll, J.W. See Garfinkel et al.

Carter, J.B., A Letter from the Editor-in-Chief. . . . . . . . . . . . . . . . . . . . . . . . . . . . . . .477-78

- From the Editor-in-Chief: New Statement of Purpose for the AJA . . . . . . . . . . . . . . 331-32

Chang, S.Y. See Garfinkel et al.

Choi, G. See Garfinkel et al.

Clerkin, C.C., and B.L. Taylor, Online Encounters with Museum Antiquities . . . . . . . . . . . . . . 165-75

Colesniuc, S.M. See Janko et al.

David, A. See Garfinkel et al.

DeGrado, J., Syrian Fashion, Assyrian Style: Clothing Syro-Anatolia in Ninth-Century BCE

Assyrian Art . . . . . . . . . . . . . . . . . . . . . . . . . . . . . . . . . . .479-504

Donnelly, A. See Leidwanger et al.

Elkins, N.T., Libertas and Freedom from Financial Burdens in the Reigns of Trajan and Hadrian. . . . . .223-45

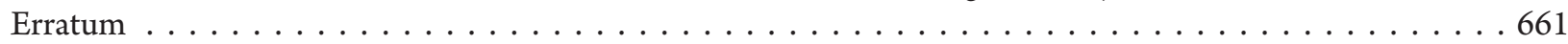

Garfinkel, Y., M.G. Hasel, M.G. Klingbeil, I. Kreimerman, M. Pytlik, J.W. Carroll, J.W.B.

Waybright, H.-G. Kang, G. Choi, S.Y. Chang, S. Hong, A. David, I. Weissbein, and

N. Silverberg, The Canaanite and Judean Cities of Lachish, Israel: Preliminary Report of

the Fourth Expedition, 2013-2017 . . . . . . . . . . . . . . . . . . . . . . . . . . . . . . .419-59

Graham, A.S., Reading Visual Cues on the So-called Archive Wall at Aphrodisias: A Cognitive

Approach to Monumental Documents . . . . . . . . . . . . . . . . . . . . . . . 571-601

Greene, E.S. See Leidwanger et al.

Hasel, M.G. See Garfinkel et al.

Haug, B., Politics, Partage, and Papyri: Excavated Texts Between Cairo and

Ann Arbor (1924-1953) . . . . . . . . . . . . . . . . . . . . . . . . . . . . . . . . . . 143-63

Hong, S. See Garfinkel et al.

Ionescu, M. See Janko et al.

Janko, R., S.M. Colesniuc, M. Ionescu, and I. Pâslaru, Excavating and Conserving Europe's

Oldest Books: A Papyrus from Mangalia on the Black Sea (P. Callatis 1) . . . . . . . . . . . 6 65-89

Kang, H.-G. See Garfinkel et al.

Kennell, N.M., Cultural History and Memory in the Stadium-Gymnasium Complex at Messene . . . . . .503-33

Klingbeil, M.G. See Garfinkel et al.

Kreimerman, I. See Garfinkel et al.

Lamont, J.L., Cursing Theophrastos in Paros . . . . . . . . . . . . . . . . . . . . . . .207-22

Lancaster, L. See Smith and Lancaster. 
Legarra Herrero, B., and M. Martinón-Torres, Heterogeneous Production and Enchained Consumption: Minoan Gold in a Changing World (ca. 2000 BCE) . . . . . . . . . . . . . . . 333-60 Leidwanger, J., E.S. Greene, and A. Donnelly, The Sixth-Century CE Shipwreck at Marzamemi . . . . . 283-317 Macaulay-Lewis, E., Making The Met, 1870-2020: A Universal Museum for the 21st Century . . . . . . . 319-30 Martens, B., Delos and the Late Hellenistic Art Trade: Archaeological Directions . . . . . . . . . . . . . 535-70 Martinón-Torres, M. See Legarra Herrero and Martinón-Torres.

Moore, A.M.T., Nancy C. Wilkie, $1942-2021$. . . . . . . . . . . . . . . . . . . . . . . . . . . . . . . .657-60

Moullou, D., Shedding Light on the Kothon: Vases with Inward Downturned Rims Revisited. . . . . . . 183-206

Ojeda, D., Fragments of Roman Sculptures from Hadrian's Villa . . . . . . . . . . . . . . . . . . . . . . 391-417

Osypińska, M. See Woźniak et al.

Özgen, İ., E.P. Baughan, and E. Ünlü, Hacımusalar Höyük in the Early Bronze Age . . . . . . . . . . . .603-38

Pâslaru, I. See Janko et al.

Pulak, C. See Carlson and Pulak.

Pytlik, M. See Garfinkel et al.

Rądkowska, J.K. See Woźniak et al.

Rogers, D.K., Sensing Water in Roman Greece: The Villa of Herodes Atticus at Eva-Loukou and the Sanctuary of Demeter and Kore at Eleusis . . . . . . . . . . . . . . . . 91-122

Sağlamtimur. See Baysal and Sağlamtimur.

Shaya, J., Lingering Tropes and Noteworthy Narratives in Recent Archaeology Exhibitions . . . . . . . 639-55

Sidebotham, S.E. See Woźniak et al.

Silverberg, N. See Garfinkel et al.

Smith, T.J., and L. Lancaster, J.J. Coulton, $1940-2020 \ldots \ldots \ldots \ldots \ldots \ldots$. . . . . . . . . . . . . 177-80

Souza, R. See Walthall and Souza.

Stone, D.L., A Letter from the Book Review Editor $\ldots \ldots \ldots \ldots \ldots \ldots \ldots \ldots \ldots \ldots$

Taylor, B.L. See Clerkin and Taylor.

Ünlü, E. See Özgen et al.

Walthall, D.A., and R. Souza, Sortition in Hellenistic Sicily: New Archaeological Evidence from Morgantina . . . . . . . . . . . . . . . . . . . . . . . . . . . . . 361-90

Watson, G.C., The Development and Spread of Die Sharing in the Roman Provincial Coinage of Asia Minor . . . . . . . . . . . . . . . . . . . . . . . . . . . . . .123-42

Waybright, J.W.B. See Garfinkel et al.

Weissbein, I. See Garfinkel et al.

Woźniak, M.A., S.E. Sidebotham, M. Osypińska, A. Carannante, and J.K. Rądkowska, Ptolemaic

Berenike: Resources, Logistics, and Daily Life in a Hellenistic Fortress on the Red Sea Coast

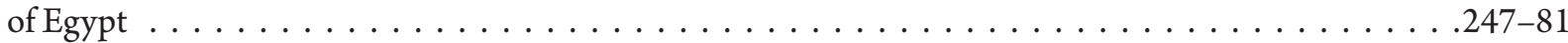

\section{ONLINE ONLY}

\section{SUPPLEMENTARY CONTENT}

Clerkin, C.C., and B.L. Taylor, Image Gallery: Online Encounters with Museum Antiquities Garfinkel, Y., M.G. Hasel, M.G. Klingbeil, I. Kreimerman, M. Pytlik, J.W. Carroll, J.W.B. Waybright, H.-G. Kang, G. Choi, S.Y. Chang, S. Hong, A. David, I. Weissbein, and N. Silverberg, Image Gallery: The Canaanite and Judean Cities of Lachish, Israel: Preliminary Report of the Fourth Expedition, 2013-2017 
Janko, R, S.M. Colesniuc, M. Ionescu, and I. Pâslaru, Image Gallery: Excavating and Conserving Europe's Oldest

Books: A Papyrus from Mangalia on the Black Sea (P. Callatis 1)

Legarra Herrero, B., and M. Martinón-Torres, Appendices: Heterogeneous Production and Enchained

Consumption: Minoan Gold in a Changing World (ca. 2000 BCE)

Macaulay-Lewis, E., Image Gallery: Making The Met, 1870-2020: A Universal Museum for the 21st Century

Özgen, İ., E.P. Baughan, and E. Ünlü, Image Gallery: Hacımusalar Höyük in the Early Bronze Age

\section{BOOK REVIEWS}

Al-Zaidi, S.-A., Rev. of Thornton, Archaeologists in Print: Publishing for the People

Barber, E.J.W., Rev. of Levy, The Genesis of the Textile Industry from Adorned Nudity to Ritual Regalia: The Changing Role of Fibre Crafts and Their Evolving Techniques of Manufacture in the Ancient Near East from the Natufian to the Ghassulian

Becker, M.J., Rev. of Mogetta, ed., Elite Burial Practices and Processes of Urbanization at Gabii: The Non-adult Tombs from Area D of the Gabii Project Excavations

Benton, J.T., Rev. of Fentress and Limane, eds., Volubilis après Rome: Les fouilles UCL/INSAP, 2000-2005

Cartwright, R., Rev. of Hillerdal and Ilves, eds., Re-imagining Periphery: Archaeology and Text in Northern Europe from Iron Age to Viking and Early Medieval Periods

Chavela, K., Rev. of Dimakis and Dijkstra, eds., Mortuary Variability and Social Diversity in Ancient Greece: Studies on Ancient Greek Death and Burial

Cheung, C., Rev. of Van Oyen, The Socio-Economics of Roman Storage: Agriculture, Trade, and Family

Clarke, J.R., Rev. of Ivleva and Collins, eds., Un-Roman Sex: Gender, Sexuality, and Lovemaking in the Roman Provinces and Frontiers

Crawford-Brown, S., Rev. of Collins-Clinton, Cosa: The Sculpture and Furnishings in Stone and Marble

Davis, J.L., Rev. of Forsén, ed., Thesprotia Expedition IV: Region Transformed by Empire

Dixon, H., Rev. of Gorzelany, Macedonia-Alexandria: Monumental Funerary Complexes of the Late Classical and Hellenistic Age

Düring, B.S., Rev. of Faust, The Neo-Assyrian Empire in the Southwest: Imperial Domination and Its Consequences

Erickson, B., Rev. of Lemos and Tsingarida, eds., Beyond the Polis: Rituals, Rites, and Cults in Early and Archaic Greece (12th-6th Centuries BC)

Goodman, P.J., Rev. of Emmerson, Life and Death in the Roman Suburb

Gordon, J.M., Rev. of Kearns and Manning, eds., New Directions in Cypriot Archaeology

Gosner, L.R., Rev. of Duckworth and Wilson, eds., Recycling and Reuse in the Roman Economy

Graham, E.-J., Rev. of Kiernan, Roman Cult Images: The Lives and Worship of Idols from the Iron Age to Late Antiquity

Hardman, A., Rev. of Cousins, The Sanctuary at Bath in the Roman Empire

Hobson, M.S., Rev. of Scheding, Urbaner Ballungsraum im römischen Nordafrika: Zum Einfluss von mikroregionalen Wirschafts- und Sozialstrukturen auf den Städtebau in der Africa Proconsularis

Holland Goldthwaite, L., Rev. of Graham, Reassembling Religion in Roman Italy

Horowitz, M.T., Rev. of Fischer and Bürge, Two Late Cypriot City Quarters at Hala Sultan Tekke: The Söderberg Expedition 2010-2017

Koloski-Ostrow, A.O., Rev. of Locicero, Liquid Footprints: Water, Urbanism, and Sustainability in Roman Ostia

Kouremenos, A., Rev. of Rojas, The Pasts of Roman Anatolia: Interpreters, Traces, Horizons

Kubiak-Schneider, A., Rev. of Mazzilli, Rural Cult Centres in the Hauran: Part of the Broader Network of the Near East (100 BC-AD 300)

Lancaster, J., Rev. of Jonasch, ed., The Fight for Greek Sicily: Society, Politics, and Landscape 
Lund, J., Rev. of Papantoniou, Michaelides, and Dikomitou-Eliadou, eds., Hellenistic and Roman Terracottas

Lusnia, S.S., Rev. of Longfellow and Perry, eds., Roman Artists, Patrons, and Public Consumption: Familiar Works Reconsidered

Madole Lewis, S., Rev. of Crowley, The Phantom Image: Seeing the Dead in Ancient Rome

Maeir, A.M., Rev. of Prag, Excavations by K.M. Kenyon in Jerusalem 1961-1967. Vol. 6, Sites on the Edge of the Ophel

Master, D.M., Rev. of Ilan, Dan IV: The Iron Age I Settlement. The Avraham Biran Excavations (1966-1999)

Middleton, G.D., Rev. of Lemos and Kotsonas, eds., A Companion to the Archaeology of Early Greece and the Mediterranean

Mogetta, M., Rev. of Yegül and Favro, Roman Architecture and Urbanism: From the Origins to Late Antiquity

Moses, V.C., Rev. of Allen, ed., The Role of Zooarchaeology in the Study of the Western Roman Empire

Mugnai, N., Rev. of Dell'Acqua, La decorazione architettonica di Brescia romana: Edifici pubblici e monumenti funerari dall'Età repubblicana alla tarda antichità

Olshanetsky, H., Rev. of Stern, Writing on the Wall: Graffiti and the Forgotten Jews of Antiquity

Papalexandrou, N., Rev. of Walter, Clemente, and Niemeier, Ursprung und Frühzeit des Heraion von Samos. Part 1, Topographie, Architektur und Geschichte

Petrakis, V., Rev. of Gorogianni, Pavúk, and Girella, eds., Beyond Thalassocracies: Understanding Processes of Minoanisation and Mycenaeanisation in the Aegean

Poehler, E., Rev. of Pollard, Bombing Pompeii: World Heritage and Military Necessity

Rauh, N.K., Rev. of Berlin and Kosmin, eds., Spear-Won Land: Sardis from the King's Peace to the Peace of Apamea

Reger, G., Rev. of Duckworth, Cuénod, and Mattingly, eds., Mobile Technologies in the Ancient Sahara and Beyond

- Rev. of Sterry and Mattingly, eds., Urbanisation and State Formation in the Ancient Sahara and Beyond

Roller, L.E., Rev. of Blakely and Collins, eds., Religious Convergence in the Ancient Mediterranean

Rothaus, R.M., Rev. of Roberston Brown, Corinth in Late Antiquity: A Greek, Roman and Christian City

Samuels, J.T., Rev. of Boschi, Giorgi, and Vermeulen, eds., Picenum and the Ager Gallicus at the Dawn of the Roman Conquest: Landscape Archaeology and Material Culture

Schneider, B., Rev. of Eppihimer, Exemplars of Kingship: Art, Tradition, and the Legacy of the Akkadians

Sebastiani, A., Rev. of Patterson, Witcher, and Di Giuseppe, The Changing Landscapes of Rome's Northern

Hinterland: The British School at Rome's Tiber Valley Project

Small, D.B., Rev. of Hodos, The Archaeology of the Mediterranean Iron Age: A Globalising World c. 1100-600 BCE

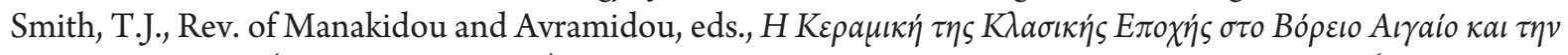

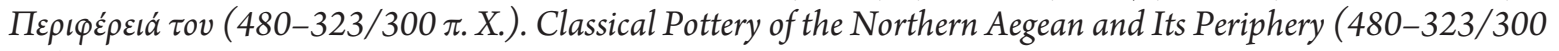

BC): Proceedings of the International Archaeological Conference, Thessaloniki, 17-20 May 2017

Stone, P.J., Rev. of Stern, Excavations at Maresha Subterranean Complex 169: Final Report, Seasons 2000-2016

Stone, S., Rev. of Masci, Archeologia a Camarina: Ceramiche e utensili in età ellenistica

Taylor, M.J., Rev. of Fitzpatrick and Haselgrove, eds., Julius Caesar's Battle for Gaul: New Archaeological Perspectives

Thomason, A., Rev. of Gansell and Shafer, eds., Testing the Canon of Ancient Near Eastern Art and Archaeology Trakadas, A., Rev. of Leidwanger, Roman Seas: A Maritime Archaeology of Eastern Mediterranean Economies van Dommelen, P., Rev. of Zuchtriegel, Colonization and Subalternity in Classical Greece: Experience of the Nonelite Population

Walas, A.H., Rev. of Symonds, Protecting the Roman Empire: Fortlets, Frontiers, and the Quest for Post-conquest Security 